\title{
17a-ethinyl estradiol induces behavioral and reproductive damages in zebrafish (Danio rerio)
}

\author{
Schuster, A.C.; Rodrigues, G.Z.P.; Zwetsch, B.G.; Garcia, A.L.H. \& Gehlen, G. \\ Laboratório de Histologia Comparada - Universidade FEEVALE
}

Received March 11, 2019; Accept August 30, 2019

\begin{abstract}
Synthetic estrogen $17 \alpha$-ethinyl estradiol (EE2) is recognized for its ability to cause endocrine disruption in aquatic organisms and its high resistance to environmental degradation, being found in Brazilian waterbodies up to $100 \mathrm{ng} \mathrm{L}^{-1}$. Thus, the aim of this study was to evaluate the exploratory behavior and the histological effects on zebrafish gonads, caused by environmentally relevant concentrations of EE2. Females were exposed to nominal concentrations of $25 \mathrm{ng} \mathrm{L}^{-1}$ and $100 \mathrm{ng} \mathrm{L}^{-1} \mathrm{EE} 2$ for 21 days. After that, a behavioral and histological analysis of gonads was performed. The EE2 caused the reduction of the exploratory activity of the animals, when observed the behavior, and an acceleration of the maturation process of the oocytes evaluated in the histological analysis. Considering the results obtained after the exposure to EE2, we highlight the concern about the potential risks it may cause to the aquatic biota, alerting to the need to control and monitor these micropollutants present in Brazilian water resources.
\end{abstract}

Key words: endocrine disruptor, histopathology, exploratory behavior

\section{INTRODUCTION}

$17 \alpha$-ethinyl estradiol (EE2) is an estrogenic compound used in the formulation of oral contraceptives, recognized as an endocrine disruptor, which can potentially cause effects on aquatic organisms (Cunha et al., 2016). Because it is a widely used drug in humans and has its form of excretion through the urine and feces, which enter the water treatment plants (WWTPs) (Ternes et al., 1999; Balest et al., 2008; Wang et al., 2012; Bai \& Acharya, 2019), there is an environmental concern, since this estrogen has a high resistance to degradation (Aris et al., 2014) and even at low concentrations may cause risks to the aquatic environment (Kidd et al., 2007; Smolarz et al., 2017).

Water treatment plants that use activated sludge are unable to remove EE2 from wastewater, leading to the accumulation of EE2 (Ghiselli, 2007; Forrez et al., 2009; Zhao et al., 2018; Taseidifar et al., 2017), especially in urbanized areas (Chang \& Huang, 2010). The concentrations reported in the literature range from $62 \mathrm{ng} \mathrm{L}^{-1}$ in WWTPs to 0.5 and 8.7 ng $\mathrm{L}^{-1}$ in drinking water (Atkinson et al., 2012; Larcher \& Yargeau, 2013; Li et al., 2013) presenting higher values than the predictive non-effect concentration (PNEC) $\left(0.002 \mathrm{ng} \mathrm{L}^{-1}\right)$, and characterizing this question as a public health problem. In addition, according to Barel-Cohen et al. (2006), the substance could be detected up to $100 \mathrm{~km}$ along a river.

Several studies have reported remains of EE2 as a cause for biochemical, histopathological, behavioral and reproductive process dysfunctions and damages on living organisms (Cunha et al., 2016). Such damages may vary depending on the concentration and species used (Aris et al., 2014). Fish are among the most investigated organisms, given their environmental exposure to this and others substances (Dalzochio et al., 2016; Altenhofen et al., 2017; Nabinger et al., 2017; Rodrigues et al., 2018).

Zebrafish (Danio rerio) are considered the ideal model for ecotoxicological studies, as a result of their high sensitivity and ease of manipulation in the laboratory. Speed of sexual maturation (4 months) lend zebrafish to be the suitable model for reproductive studies (Luzio et al., 2016a). Zebrafish 
hypothalamic-pituitary-interrenal axis resemble human hypothalamic-pituitary-adrenal axis and are thus suited to behavioral studies as well (Alsop \& Vijayan, 2009; Altenhofen et al., 2017a).

The damage caused by EE2 in zebrafish exposed in the early stages of larval development to adult life has been reported before. Baatrup and Henriksen (2015) showed changes in reproductive behavior, while Luzio et al. (2015) reported accelerated development of the fish and its gonads exposing embryos to EE2 for 60 days. However, for numerous substances, it has been shown that exposures in the early stages of zebrafish are more toxic than in adult life, due to the greater sensitivity of embryos and larvae to adult fish (Altenhofen et al., 2017b; Gao et al., 2019). In other species of freshwater fish, reproductive alterations such as feminization of males and morphological changes in the gonads have also been reported (Scholz \& Gutzeit, 2000; Mortensen \& Arukwe, 2007).

Therefore, the aim of this study was to chronically expose adult zebrafish to EE2 concentrations similar to those found in Brazilian WWTPs, thus to evaluate the exploratory behavior and histological alterations in their gonads.

\section{MATERIALS AND METHODS}

\section{Determination of hormone concentrations and solution preparation}

Based on a recent literature review on the occurrence of EE2 in the environment (Aris et al., 2014), the concentrations of 25 and $100 \mathrm{ng} \mathrm{L}^{-1}$ were chosen for the experiments considering the relevance and environmental occurrence. So the exposure concentrations (nominal) of EE2 (Sigma-Aldrich, USA) were determined based on average values available in the literature for Brazilian WWTPs (Bila \& Dezotti, 2007; Barcellos,

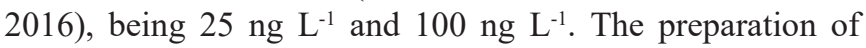
the stock solution was carried out by diluting the estrogen in absolute ethanol (Neon Comercial, BR) (1 mg mL-1, resulting in a final concentration of $0.01 \%$ ethanol per liter of water in the final aquaria of the experiment). Since the ethanol used as solvent did not exceed the limits set by the Organization for Economic Cooperation Development, the control group was reared only with fresh water (OECD, 2012), as well as other studies conducted in the area (Forner-Piquer et al., 2018).

\section{Animal Experimental Procedure}

This study preserves the ethical aspects related to the research animals and was approved by the Feevale University Ethics Committee on Animal Use, on February 21, 2017 , according to protocol $n^{\circ}$ 03.16.049.

Adult females of zebrafish were purchased from a commercial breeder, from the city of Porto Alegre, RS. Acclimatization of the animals occurred for seven days in aquariums (12 L) with reconstituted water (ISO, 1996) $(\mathrm{pH}$ at 7.0, water hardness: $75-100 \mu \mathrm{g} \mathrm{L}^{-1}$, temperature of $26 \pm 2$ $\left.{ }^{\circ} \mathrm{C}\right)$ with constant artificial aeration, in controlled temperature $\left(24^{\circ} \mathrm{C}\right)$ with cycles of 12 hours of light and 12 hours of dark. After acclimatization, the animals ( $n=30$ per group) were transferred to aquarium $(2 \mathrm{~L})$ (respecting the density of 5 animals per liter of water) and exposed to EE2 (25 and 100

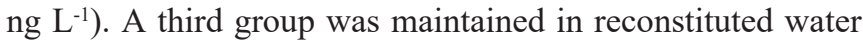
(control group). The exhibition comprised 21 days, and the renewal of $50 \%$ of the water of each aquarium was done every 48 hours. Feeding occurred daily (Alcon $\AA)$.

\section{Behavioral analysis}

For the exploratory behavior analysis, the protocol established by Cachat et al. (2011a) was followed, where at the end of the experiment the animals were filmed individually for 6 minutes in trapezoid format aquarium $(2.5 \mathrm{~L})$. The images were analyzed through the software Ethovision R XT7, which evaluated the parameters of average speed, distance traveled, number of entrances in the upper and lower areas of the aquarium, and the time that remained in each area.

\section{Histological analysis}

After the behavioral analysis, the animals were sacrificed according to the protocol established by the Feevale University Ethics Committee on Animal Use. Fish ( $\mathrm{n}=9$ per group) were fixed in $4 \%$ formaldehyde for 8 hours and dehydrated in a gradual series of ethanol, paraffin embedded, sectioned in a rotating microtome $(10 \mu \mathrm{m})$ and stained with Hematoxylin and Eosin (HE). An optical microscope was used for the analysis at a magnification of 100x, in which the number of pre-vitellogenic and vitellogenic oocytes was quantified in 08 fields per animal, totaling 72 fields per group.

\section{Statistical analysis}

For the statistical analysis, the normality of the data was tested, and the Analysis of Variance (ANOVA) test was applied, followed by Tukey post-hoc when appropriate. Differences were considered significant when $\mathrm{p}<0.05$ and data were expressed as mean \pm standard deviation.

\section{RESULTS}

During the 21 days of exposure, 4 animals of the $100 \mathrm{ng}$ $\mathrm{L}^{-1}$ concentration group and 1 of the $25 \mathrm{ng} \mathrm{\textrm {L } ^ { - 1 }}$ group died. A significant decrease in mean velocity was observed in fish exposed to a concentration of $100 \mathrm{ng} \mathrm{L}^{-1}$ when compared to the control group $(p=0.001)$ (Figure 1). Fish exposed at concentrations of $25 \mathrm{ng} \mathrm{L}^{-1}$ and $100 \mathrm{ng} \mathrm{L}^{-1}$ entered less frequently in the lower aquarium area than in the control group $(p=0.0006)$ (Figure 2). However, there were no significant differences between groups for the parameters of distance traveled, number of entries in the upper area of the aquarium and time of permanence in the lower and upper areas $(\mathrm{p}<0.05)$ (Table 1).

In relation to the histological analysis, a significant increase in the number of vitellogenic oocytes was observed in the animals exposed to $100 \mathrm{ng} \mathrm{L}^{-1}$ when compared with 


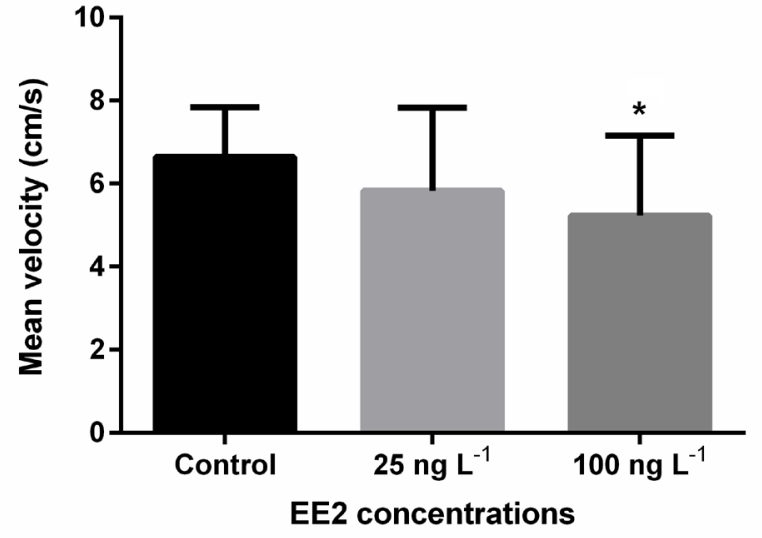

Figure 1: Mean velocity developed by the animals exposed at EE2 (Data expressed in mean \pm standard deviation, and asterisk represents statiscal difference in relation to the control group).

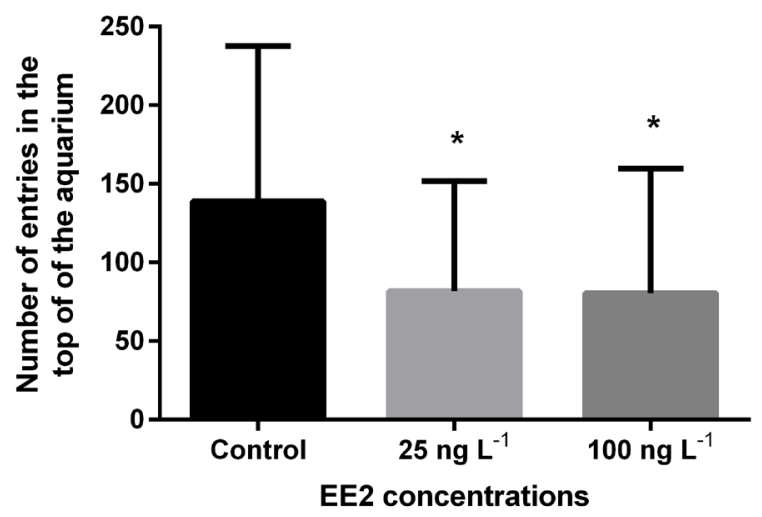

Figure 2: Number of entries in the top of the aquarium by the animals exposed at EE2. (Data expressed in mean \pm standard deviation, and asterisk represents statiscal difference in relation to the control group). the control $(\mathrm{p}=0.0034)$ and $25 \mathrm{ng} \mathrm{L^{-1 }}(\mathrm{p}=0.0007)$ (Figure 3 ), characterizing an acceleration of the maturation process. On the other hand for pre-vitellogenic oocytes, there was no significant difference $(p=0.65)$. No morphological changes were observed in the analyzed fields (Figure 4).

\section{DISCUSSION}

The behavioral repertoire of the zebrafish is diverse and allows the analysis of a serie of parameters (Gerlai et al., 2000). The natural tendency of zebrafish is to spend most of the time in the background when introduced into a new environment and then gradually explore the upper area of the test tank (Levin et al., 2007). The fish at the concentrations of $25 \mathrm{ng} \mathrm{L}^{-1}$ and $100 \mathrm{ng} \mathrm{L}^{-1}$ had a significant decrease of entrances in the lower area of the aquarium, compared to the control group, indicating an exploratory decrease. The significant decrease in the mean velocity developed by the animals of the $100 \mathrm{ng} \mathrm{L}^{-1}$ concentration when compared to the control group can be explained according to the study reported by Gerlai et al. (2009), where anxious animals can constantly change their swimming speed while unaffected individuals move at a fairly normal and continuous pace.

It is known that the reduction of zebrafish swimming activity indicates an increased stress phenotype. Under such conditions, the serotonergic system (associated with stress in fish) causes high levels of serotonin in the brain to stimulate the release of gonadotrophins in the pituitary gland, which controls gonad maturation and egg release. Therefore, behavior changes can directly influence reproductive behavior (Prassad et al., 2015; Winberg \& Thörnqvist, 2016).

Table 1: Behavioral parameters of zebrafish exposed to EE2. (Values expressed as mean \pm standard deviation).

\begin{tabular}{|c|c|c|c|c|}
\hline & $\begin{array}{l}\text { Travelled distance } \\
\qquad(\mathrm{cm})\end{array}$ & Top frequency & Time in top & Time in bottom (s) \\
\hline Control & $1142,94 \pm 524,91$ & $50,52 \pm 32,06$ & $33,54 \pm 24,63$ & $212,20 \pm 73,05$ \\
\hline $25 \mathrm{ng} \mathrm{L}^{-1}$ EE2 & $1372,76 \pm 654,03$ & $54,46 \pm 60,12$ & $41,02 \pm 39,03$ & $247,94 \pm 80,06$ \\
\hline $100 \mathrm{ng} \mathrm{L}^{-1} \mathrm{EE} 2$ & $1059,95 \pm 686,82$ & $43,54 \pm 66,80$ & $38,18 \pm 40,49$ & $218,19 \pm 115,09$ \\
\hline p & 0,18 & 0,9 & 0,7 & 0,3 \\
\hline
\end{tabular}

A)

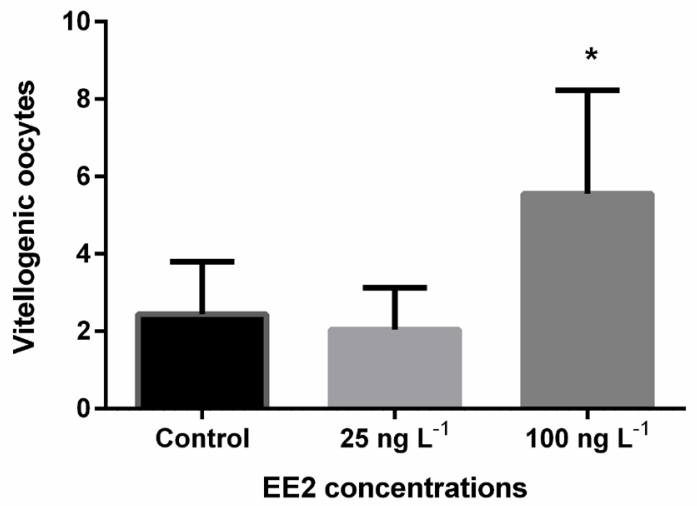

B)

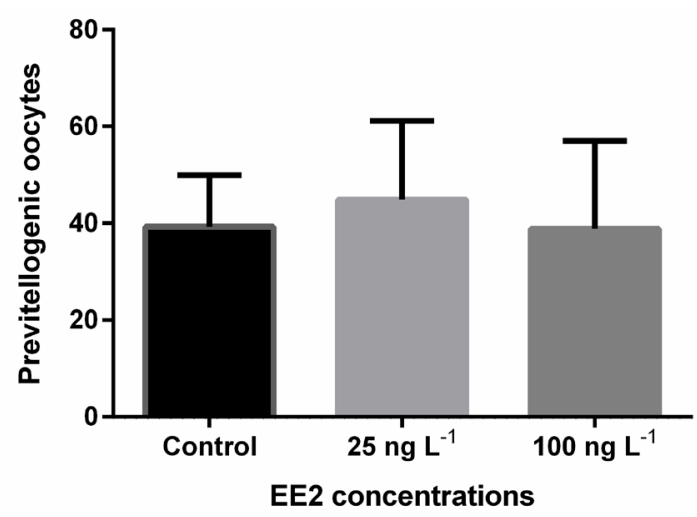

Figure 3: Quantification of vitellogenic (A) and pre-vitellogenic (B) oocytes. (Data expressed in mean \pm standard deviation, and asterisk represents statiscal difference in relation to the control group). 

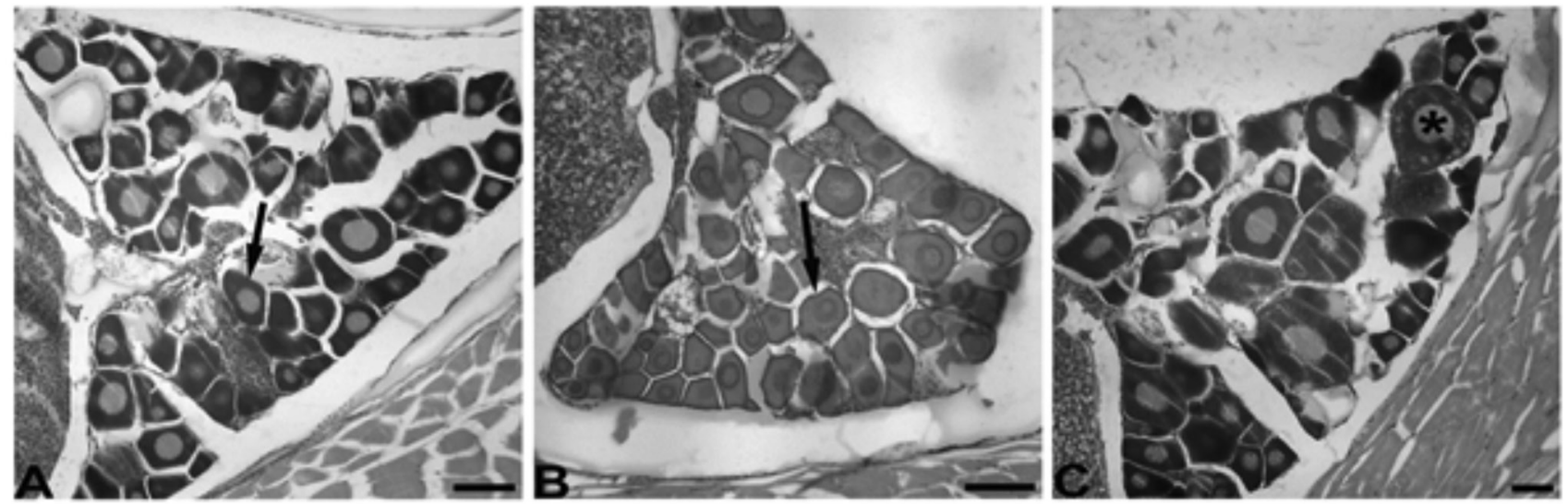

Figure 4: Histological slides of zebrafish ovaries. To observe in A and B the pre-vitellogenic oocytes (black arrow) of the animals of the control group and 25 ng $\mathrm{L}^{-1} \mathrm{EE} 2$ respectively. In C, observe the vitellogenic oocytes of animals exposed to $100 \mathrm{ng} \mathrm{L}^{-1} \mathrm{EE} 2$. Scale bars represents $100 \mathrm{um}$.

Goundadkar and Pancharatna (2017) studied the effects of $5 \mathrm{ng} \mathrm{L}^{-1}$ concentration of EE2 in zebrafish and demonstrated that only after 30 days of exposure a significant decrease in swimming time occurs, with a corresponding increase in immobility. The movement of the fish was confined largely to the lower half of the aquarium over the 75 days of exposure corroborating to the present experiment.

According to Scott and Sloman (2004) behavioral changes can have shocking ecological consequences. The authors report that reducing the ability to prevent predators can directly affect the size and structure of fish populations and that interference in social interactions associated with territoriality and dominance may influence the search for food and shelter.

They also point out that changes in behavior may reflect partner selection, make fertilization unsuccessful, or compromise the survival of offspring. For example, males (Danio rerio) exposed to ethinylestradiol $\left(25 \mathrm{ng} \mathrm{L}^{-1}\right)$ were not able to induce spawning of untreated females (negative control), indicating failures in the reproductive process (Reyhanian et al., 2011).

Histological analysis showed an acceleration of the maturation process caused by a significant increase in the number of vitellogenic oocytes in animals exposed to $100 \mathrm{ng} \mathrm{L}^{-1}$ when compared to the control and $25 \mathrm{ng} \mathrm{L}^{-1}$. Studies with EE2 have shown similar results, indicating an acceleration of the oocyte maturation process in zebrafish, in which zebrafish exposed to 4 $n g L^{-1}$ of EE2 showed a trend towards higher absolute volumes of gonads causing a development of gonads when compared with the control (Luzio et al. 2016a; Luzio et al. 2016b)

In contrast, Chen et al. (2015) reported a decrease in the maturation process of ovarian follicles in zebrafish females exposed from 20 hours post-fertilization (hpf) to 45 days postfertilization (dpf) at 5 and $20 \mathrm{ng} \mathrm{L}^{-1}$ of EE2. Xu et al. (2008) also reported delayed differentiation of gonadal tissue from zebrafish exposed from $2 \mathrm{hpf}$ to 3 months of age to $10 \mathrm{ng} \mathrm{L}^{-1}$ of EE2, indicating that exposures in early life lead to different responses in relation to adult life.
The findings of this study demonstrated that EE2 in environmentally relevant concentrations and similar to those found in WWTPs around the world can modify the exploratory behavior and histology of zebrafish gonads after 21 days of exposure. Due to the findings of abnormal behavior and the accelerated maturation of the fish exposed to this estrogen, the importance of monitoring and controlling this substance in the aquatic environments is emphasized.

\section{ACKNOWLEDGMENT}

Feevale University for the structure, CAPES and FAPERGS for the financial support and PUCRS, especially the PhD Carla Denise Bonan for access and permission to use the software for behavior analysis.

\section{REFERENCES}

ALSOP, D., VIJAYAN, M.M. 2009. Molecular programming of the corticosteroid stress axis during zebrafish development. Comp. Biochem. Physiol. Part A: Mol. Integr. Physiol., 153(1): 49-54. https://doi.org/10.1016/j.cbpa.2008.12.008

ALSOP, D., VIJAYAN, M.M. 2009. The zebrafish stress axis: Molecular fallout from the teleost-specific genome duplication event. Gen. Comp. Endocr., 161(1): 62-66. https://doi. org/10.1016/j.ygcen.2008.09.011

ALTENHOFEN, S., WIPRICH, M.T., NERY, L.R., LEITE, C.E., VIANNA, M.R.M.R., BONAN, C.D. 2017. Manganese(II) chloride alters behavioral and neurochemical parameters in larvae and adult zebrafish. Aquat. Toxicol., 182: 172-183. https:// doi.org/10.1016/j.aquatox.2016.11.013

ALTENHOFEN, S., NABINGER, D.D., WIPRICH, M.T., PEREIRA, T.C.B., BOGO, M.R., BONAN, C.D. 2017. Tebuconazole alters morphological, behavioral and neurochemical parameters in larvae and adult zebrafish (Danio rerio). Chemosphere, 180: 483-490. https://doi.org/10.1016/j.chemosphere.2017.04.029

ARIS, A.Z., SHAMSUDDIN, A.S., PRAVEENA, S.M. 2014. Occurrence of $17 \alpha$-ethynylestradiol (EE2) in the environment and effect on exposed biota: a review. Environ. Int., 69: 104-119. http://dx.doi.org/10.1016/j.envint.2014.04.011

ATKINSON, S.K., MARLATT, V.L., KIMPE, L.E., LEAN, D.R.S., TRUDEAU, V.L., BLAIS, J.M. 2012. The occurrence of steroidal 
estrogens in south-eastern Ontario wastewater treatment plants. Sci. Total Environ., 430: 119-125. https://doi.org/10.1016/j. scitotenv.2012.04.069

BAATRUP, E., HENRIKSEN, P.G. 2015. Disrupted reproductive behavior in unexposed female zebrafish (Danio rerio) paired with males exposed to low concentrations of $17 \alpha$-ethinylestradiol (EE2). Aquat. Toxicol., 160: 197-204. https://doi.org/10.1016/j. aquatox.2015.01.020

BAI, X., ACHARYA, K. 2019. Removal of seven endocrine disrupting chemicals (EDCs) from municipal wastewater effluents by a freshwater green alga. Environ. Pollut., 247: 534540. https://doi.org/10.1016/j.envpol.2019.01.075

BALEST, L., LOPEZ, A., MASCOLO, G., DI IACONI, C. 2008. Removal of endocrine disrupter compounds from municipal wastewater using an aerobic granular biomass reactor. Biochem. Eng. J, 41: 288-294. https://doi.org/10.1016/j.bej.2008.05.015

BAREL-COHEN, K., SHORE, L. S., SHEMESH, M., WENZEL, A.; MUELLER, J., KRONFELD-SCHOR, N. 2006. Monitoring of natural and synthetic hormones in a polluted river. Biochem. Eng. J., 78: 16-23. https://doi.org/10.1016/j.jenvman.2005.04.006

CACHAT, J.M., CANAVELLO, P.R., EIKHAYAT, S.I., BARTELS, B.K., HART, P.C., ELEGANTE, M.F., BEESON, E.C., LAFFOON, A.L., HAYMORE, W.A.M., TIEN, D.H., TIEN, A.K., MOHNOT, S., KALUEFF, A.V. 2010. VideoAided Analysis of Zebrafish Locomotion and Anxiety-Related Behavioral Responses. Neuromethods, 51: 1-14.

CHANG, C., HUANG, S. 2010. Determination of the steroid hormone levels in water samples by dispersive liquid-liquid microextraction with solidification of a floating organic drop followed by high-performance liquid chromatography. Anal. Chim. Acta, 662: 39-43. https://doi.org/10.1016/j. aca.2010.01.003

CHEN, P., LI, S., LIU, L., XU, N. 2015. Long-term effects of binary mixtures of $17 \alpha$-ethinyl estradiol and dibutyl phthalate in a partial life-cycle test with zebrafish (Danio rerio). Environ. Toxicol. Chem., 34(3): 518-526. https://doi.org/10.1002/etc.2803

CUNHA, D.L., SILVA, S.M.C., BILA, D.M., OLIVEIRA, J.L.M., SARCINELLI, P.N., LARENTIS, A.L. 2016. Regulation of the synthetic estrogen $17 \alpha$-ethinylestradiol in water bodies in Europe, the United States, and Brazil. Cad. Saúde Pública, 32(3). https://doi.org/10.1590/0102-311X00056715

DALZOCHIO, T., GOLDONI, A., RODRIGUES, G.Z.P., PETRY, I.E., SILVA, L.B., GEHLEN, G. 2016. Gill histopathology and micronucleus test of Astyanax jacuhiensis (Cope, 1894) (Teleostei, Characidae) to evaluate effects caused by acute exposure to aluminum. Biotemas, 29(1): 75-83. https://doi. org/10.5007/2175-7925.2016v29n1p75

FORNER-PIQUER, I., SANTANGELI, S., MARADONNA, F., RABBITO, A., PISCITELlI, F., HABIBI, H.R., MARZO, V.C., CARNEVALI, O. 2018. Disruption of the gonadal endocannabinoid system in zebrafish exposed to diisononyl phthalate. Environ. Pollut., 241: 1-8. https://doi.org/10.1016/j. envpol.2018.05.007

FORREZ, I., CARBALLA, M., NOPPE, H., BRABANDER, H., BOON, N., VERSTRAETE, W. 2009. Influence of manganese and ammonium oxidation on the removal of $17 \alpha$-ethinylestradiol (EE2). Water Res., 43: 77-86. https://doi.org/10.1016/j. watres.2008.10.006

GAO, Y., ZHANG, Y., FENG, J., ZHU, L. 2019. Toxicokinetictoxicodynamic modeling of cadmium and lead toxicity to larvae and adult zebrafish. Environ. Pollut., 251: 221-229. https://doi. org/10.1016/j.envpol.2019.05.003

GERLAI, R., LAHAV, M., GUO, S., ROSENTHAL, A. 2000.
Drinks like a fish: zebrafish (Danio rerio) as a behavior genetic model to study alcohol effects. Pharmacol. Biochem. Be., 67(1): 773-782. https://doi.org/10.1016/S0091-3057(00)00422-6

GERLAI, R., FERNANDES, Y., PEREIRA, T. 2009. Zebrafish (Danio rerio) responds to the animated image of a predator: Towards the development of an automated aversive task. Behav. Brain Res., 201(2): 318-324. https://doi.org/10.1016/j. bbr.2009.03.003

GHISELLI, G., JARDIM, W.F. 2007. Interferentes endócrinos no ambiente. Quím. Nova, 30(3): 695-706. http://dx.doi. org/10.1590/S0100-40422007000300032

GOUNDADKAR, B.B., PANCHARATNA, K. 2017. Environmental Estrogen(s) induced swimming behavioural alterations in adult zebrafish (Danio rerio). Environ. Toxicol. Pharmacol., 54: 146154. https://doi.org/10.1016/j.etap.2017.07.001

KIDD, K.A., BLANCHFIELD, P.J., MILLS, K.H., PALACE, V.P., EVANS, R.E., LAZORCHAK, J.M., FLICK, R.W. 2007. Collapse of a fish population after exposure to a synthetic estrogen. PNAS USA, 104(21): 8897-8901. https://doi. org/10.1073/pnas.0609568104

LARCHER, S., YARGEAU, V. 2013. Biodegradation of $17 \alpha$-ethinylestradiol by heterotrophic bacteria. Environ. Pollut., 173: 17-22. https://doi.org/10.1016/j.envpol.2012.10.028

LEVIN, E.D., BENCAN, Z., CERUTTI, D.T. 2007. Anxiolytic effects of nicotine in zebrafish. Physiol. Behav., 90(1): 54-58. https://doi.org/10.1016/j.physbeh.2006.08.026

LI, J., JIANG, L., LIU, X., LV, J. 2013. Adsorption and aerobic biodegradation of four selected endocrine disrupting chemicals in soil-water system. Int. Biodet. Biodegr., 76: 3-7. https://doi. org/10.1016/j.ibiod.2012.06.004

LUZIO, A., MONTEIRO, S.M., ROCHA, E., FONTAÍNHASFERNANDES, A.A., COIMBRA, A.M. 2016. Development and recovery of histopathological alterations in the gonads of zebrafish (Danio rerio) after single and combined exposure to endocrine disruptors (17 $\alpha$-ethinylestradiol and fadrozole). Aquat. Toxicol., 175: 90-105. http://dx.doi.org/10.1016/j. aquatox.2016.03.014

LUZIO, A., MONTEIRO, S.M., GARCIA-SANTOS, S., ROCHA, E., FONTAÍNHAS-FERNANDES, A.A., COIMBRA, A.M. 2015. Zebrafish sex differentiation and gonad development after exposure to $17 \alpha$-ethinylestradiol, fadrozole and their binary mixture: A stereological study. Aquat. Toxicol., 166: 83-95. https://doi.org/10.1016/j.aquatox.2015.07.015

LUZIO, A., MATOS, M., SANTOS, D., FONTAÍNHASFERNANDES, A.A., COIMBRA, A.M. 2016. Disruption of apoptosis pathways involved in zebrafish gonad differentiation by $17 \alpha$-ethinylestradiol and fadrozole exposures. Aquat. Toxicol., 177: 269-284. http://dx.doi.org/10.1016/j.aquatox.2016.05.029

MORTENSEN, A.S., ARUKWE, A. 2007. Effects of $17 \alpha$-ethynylestradiol on hormonal responses and xenobiotic biotransformation system of Atlantic salmon (Salmo salar). Aquat. Toxicol., 85: 113-123. https://doi.org/10.1016/j. aquatox.2007.08.004

NABINGER, D.D., ALTENHOFEN, S., BITENCOURT, P.E.R, NERY, L.R., LEITE, C.E., VIANNA, M.R.M.R., BONAN, C.D. 2018. Nickel exposure alters behavioral parameters in larval and adult zebrafish. Sci. Total Environ., 624: 1623-1633. https://doi. org/10.1016/j.scitotenv.2017.10.057

Organisation for economic co-operation and development. OECD. 2012. Fish Toxicity Testing Framework. Series on Testing and Assessment. No. 171.

PRASAD, P., OGAWA, S., PARHAR, I.S. 2015 Role of serotonin in fish reproduction. Front. Aging Neurosci., 9: 195.

REYHANIAN, N., VOLKOVA, K., HALLGREN, S., BOLLNER, 
T., OLSSON, P., OLSÉN, H., HÄLLSTRÖM, I.P. 2011. $17 \alpha$-Ethinyl estradiol affects anxiety and shoaling behavior in adult male zebrafish (Danio rerio). Aquat. Toxicol., 105(1-2): 41-48. https://doi.org/10.1016/j.aquatox.2011.05.009

RODRIGUES, G.Z.P., SOUZA, M.S., SILVA, A.H., ZWETSCH, B.G., GEHLEN, G. 2017. Evaluation of intestinal histological damage in zebrafish exposed to environmentally relevant concentrations of manganese. Revista do Centro de Ciências Naturais e Exatas - UFSM, 40(52): 1-8.

SCHOLZ, S., GUTZEIT, H.O. 2000. 17- $\alpha$-etinilestradiol afeta a expressão genética reprodutiva, sexual e aromatase do medaka (Oryzias latipes). Aquat. Toxicol., 50: 363-373.

SCOTT, G.R., SLOMAN, K.A. 2004. The effects of environmental pollutants on complex fish behaviour: integrating behavioural and physiological indicators of toxicity. Aquat. Toxicol., 68(4): 369-392. https://doi.org/10.1016/j.aquatox.2004.03.016

SMOLRAZ, K., HALLMANN, A., ZABRZANSKA, S., PIETRASIK, A. 2017. Elevated gonadal atresia as biomarker of endocrine disruptors: Field and experimental studies using Mytilus trossulus (L.) and 17-alpha ethinylestradiol (EE2). Mar. Pollut. Bull., 120(1-2): 58-67. https://doi.org/10.1016/j. marpolbul.2017.04.007

TASEIDIFAR, M., MAKAVIPOUR, F., PASHLEY, R.M., RAHMAN, A.F.M.M. 2017. Removal of heavy metal ions from water using ion flotation. Environ. Technol., 8: 182-190. https:// doi.org/10.1016/j.eti.2017.07.002

TERNES, T.A., STUMPF, M., MUELLER, J., WILKEN, R.D., SERVOS, M. 1999. Behavior and occurrence of estrogens in municipal sewage treatment plants - I. Investigations in Germany, Canada and Brazil. Sci. Total Environ., 225(1): 81-90.

XU, H., WANG, Y., JIANG, Q., CHEN, H., SONG, H. 2008. Exposure to $17 \alpha$-ethynylestradiol impairs reproductive functions of both male and female zebrafish (Danio rerio). Aquat. Toxicol., 88(1): 1-8. https://doi.org/10.1016/j.aquatox.2008.01.020

WANG, L., YING, G., CHEN, F., ZHANG, L., ZHAO, J., LAI, H., CHEN, Z., TAO, R. 2012. Monitoring of selected estrogenic compounds and estrogenic activity in surface water and sediment of the Yellow River in China using combined chemical and biological tools. Environ. Pollut., 165: 241- 249. https://doi. org/10.1016/j.envpol.2011.10.005

WINBERG, S., THÖRNQVIST, P. 2016. Role of brain serotonin in modulating fish behavior. Curr. Zool., 62(3): 317-323. https:// doi.org/10.1093/cz/zow037

ZHAO, Y., ZHANG, K., FENT, K. 2018. Regulation of zebrafish (Danio rerio) locomotor behavior and circadian rhythm network by environmental steroid hormones. Environ. Pollut., 232: 422429. https://doi.org/10.1016/j.envpol.2017.09.057 